\title{
Development of Highly Efficient Construction Technologies for Super Long Span Bridge
}

\author{
Hee Seok Kim, Young Jin Kim, Won Jong Chin, Hyejin Yoon \\ Structural Engineering Research Division, Korea Institute of Construction Technology, Goyang-Si, South Korea \\ Email: lagoon@kict.re.kr
}

Received June 2, 2013; revised July 2, 2013; accepted July 9, 2013

Copyright (C) 2013 Hee Seok Kim et al. This is an open access article distributed under the Creative Commons Attribution License, which permits unrestricted use, distribution, and reproduction in any medium, provided the original work is properly cited.

\begin{abstract}
This paper presents highly efficient cable erection equipments and methods related to the construction of super-longspan bridges, construction technology of high towers and, technology for offshore foundations currently developed through a R\&D on accelerated and cost-saving construction technology for long-span cable bridges to secure our international competitiveness. In the field of cable erection technology, AS and PPWS equipments for highly efficient erection of cable longer than $2000 \mathrm{~m}$, world-class clamping bolt tensioning equipment and shape control system for superlong cable are under development. The technologies developed in the domain of construction of towers are tapered slip form system for the construction of $400 \mathrm{~m}$ high tower, shape and erection precision control of elevated tower and, lightweight and modular formwork for slip form system. In the domain of foundation construction, remote controlled survey equipment and analysis system for water-depth of $100 \mathrm{~m}$ and depth of $50 \mathrm{~m}$, prediction and evaluation technology of optimal load carrying capacity and settlement complying with international standard and, highly efficient hybrid foundation construction technology suitable for ground acceleration of $0.5 \mathrm{~g}$ and deep soft soil are currently developed.
\end{abstract}

Keywords: AS Equipment; PPWS Equipment; Slip Form System; Large Scale Foundation

\section{Introduction}

The globe has become borderless with the emergence of interregional, cross-border and intercontinental projects like the Asian Highway. In the worldwide trend for technological independence, the market for long-span cablesupported bridge requiring high-level of expertise offers promising prospects. Until 1990s, the long-span cablesupported bridge market was concentrated in advanced countries like Europe, USA and Japan but, at the entrance of the Post BRICs era, new and active market has opened in China, Southeast Asia and South America. Accordingly, securing technology and cost-competitiveness will widen our opportunities in penetrating this new overseas market.

The cable-supported bridge stock in Korea is composed by 12 bridges. This stock will enlarge in the near future with 20 bridges under construction or planning. Our domestic market is thus extremely demanding but the independence of our technology remains still partial. Accordingly, the necessity to secure quickly worldleading technology level through the rapid acquisition of construction technology and dedicated R\&D together with the necessity to develop technologies with the scale and organization of a national project have been emphasized. In response to such needs, the "Super-Long-Span Bridge Project" was selected as one of the 10 flagship R\&BD projects (VC-10) of the Ministry of Land, Transportation and Maritime Affairs of Korea. Experts in relevant fields are today conducting research in the form of a consortium.

The "Super-Long-Span Bridge R\&D Center" launched to secure self-reliant and independent core technologies for long-span cable-supported bridge is performing research through 4 core projects during a period of 8 years (2008-2015). Core Project 1 focuses on the development of engineering technologies, Core Project 2 on the development of strategic materials and corresponding application technologies, Core Project 3 on the development of construction technology, and Core Project 4 on the support of the test bed. Among them, Core Project 3 led by the Korea Institute of Construction Technology targets highly-efficient and cost-saving construction methods and equipments to provide footholds for our advance into foreign market. 


\section{Long-Span Bridge Market and Prospect in Korea and Overseas}

The template is used to format your paper and style the text. All margins, column widths, line spaces, and text fonts are prescribed; please do not alter them. You may note peculiarities. For example, the head margin in this template measures proportionately more than is customary. This measurement and others are deliberate, using specifications that anticipate your paper as one part of the entire journals, and not as an independent document. Please do not revise any of the current designations.

A review of the construction trend of long-span bridges overseas reveals a construction boom in the late 1990s followed by slight reduction until 2010. This trend is expected to regain activity after 2011. The total market volume of long-span bridges overseas tended to decrease after 1990s but represents now 10 - 30 trillion KRW as of year 2010. Forecast of the long-span bridges planned after 2011 previews 150 trillion KRW (Figure 1). The areas sharing the largest market are Extreme Asia (China, Japan) and Europe. USA and Southeast Asia also constitute a steady market.

The long-span bridge market in Korea represented merely a volume of 800 billion KRW in 1990s but grew up to 4.5 trillion $\mathrm{KRW}$ in 2000s to reach 6.7 trillion KRW considering only the results available currently including Yi Sun-Shin Bridge with central span of 1545 m actually under construction (Figure 2). Accordingly,

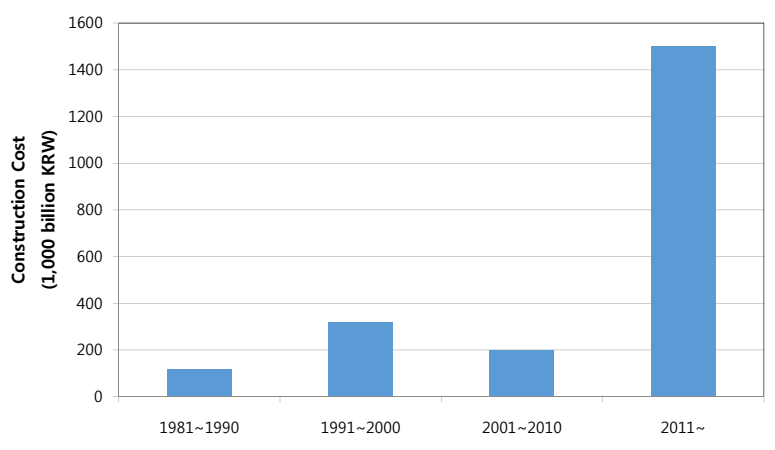

Figure 1. Volume change of long-span bridge market in foreign countries [1].

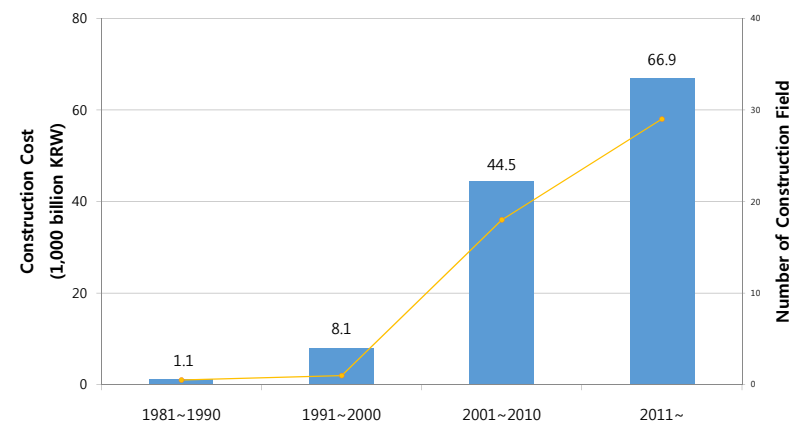

Figure 2. Evolution of long-span bridge market volume in Korea [1]. summing up the bridges currently under construction with those under planning represents a market of about 9 trillion KRW. Especially, Korea will occupy approximately $20 \%$ of the worldwide long-span bridge market in 2000s, which will rank at the second place after China [1].

\section{Development of Highly Efficient Construction Technology for Super Long Span Bridge}

The cost competitiveness of long-span bridges can be secured in terms of direct cost saving and reduction of indirect social costs by shortening the construction period and thus moving up the entrance in service of the bridge. The shortening of the construction period can be achieved not only by means of optimized process management but also by improving the erection method in correlation with the construction equipment. To that goal, this research is subdivided into three domains that are cable erection, tower erection and construction of foundation to acquire accelerated and cost saving construction technology for long-span cable-supported bridge (Figure 3). The program dedicated to cable erection undertakes the development of AS (air spinning) and PPWS (prefabricated parallel wire strand) equipments for highly efficient erection of cable longer than $2000 \mathrm{~m}$, world-class clamping bolt tensioning equipment and shape control system for super-long cable in order to develop highly efficient cable erection equipment and method for superlong-span bridges. In the domain of tower erection, tapered slipform system for the construction of $400 \mathrm{~m}$ high tower, shape and erection precision control of elevated tower and, lightweight and modular formwork for slipform system are developed to secure accelerated construction for elevated towers. In the domain of foundation construction, remote controlled survey equipment and analysis system for water-depth of $100 \mathrm{~m}$ and depth of $50 \mathrm{~m}$, prediction and evaluation technology of optimal load carrying capacity and settlement complying with international standard and, highly efficient hybrid foundation construction technology suitable for ground acceleration of $0.5 \mathrm{~g}$ and deep soft soil are currently developed to realize cost saving construction technology for large scale foundations.

\subsection{Development of Highly Efficient Cable Erection Equipment and Method}

The method for the efficient construction of super long span suspension bridge can be classified into AS and PPWS methods according to the method chosen for the erection of the main cables. Need is also for a system enabling sag measurement, tension control and management of construction error to control the shape of the 


\section{ACQUISITION OF THE CONSTRUCTION TIME SHORTENING AND COST SAVING TYPE LONG SPAN CABLE BRIDGE CONSTRUCTION TECHNOLOGIES}

\section{RESULTS FROM DETAILED ASSIGNMENT GOALS}

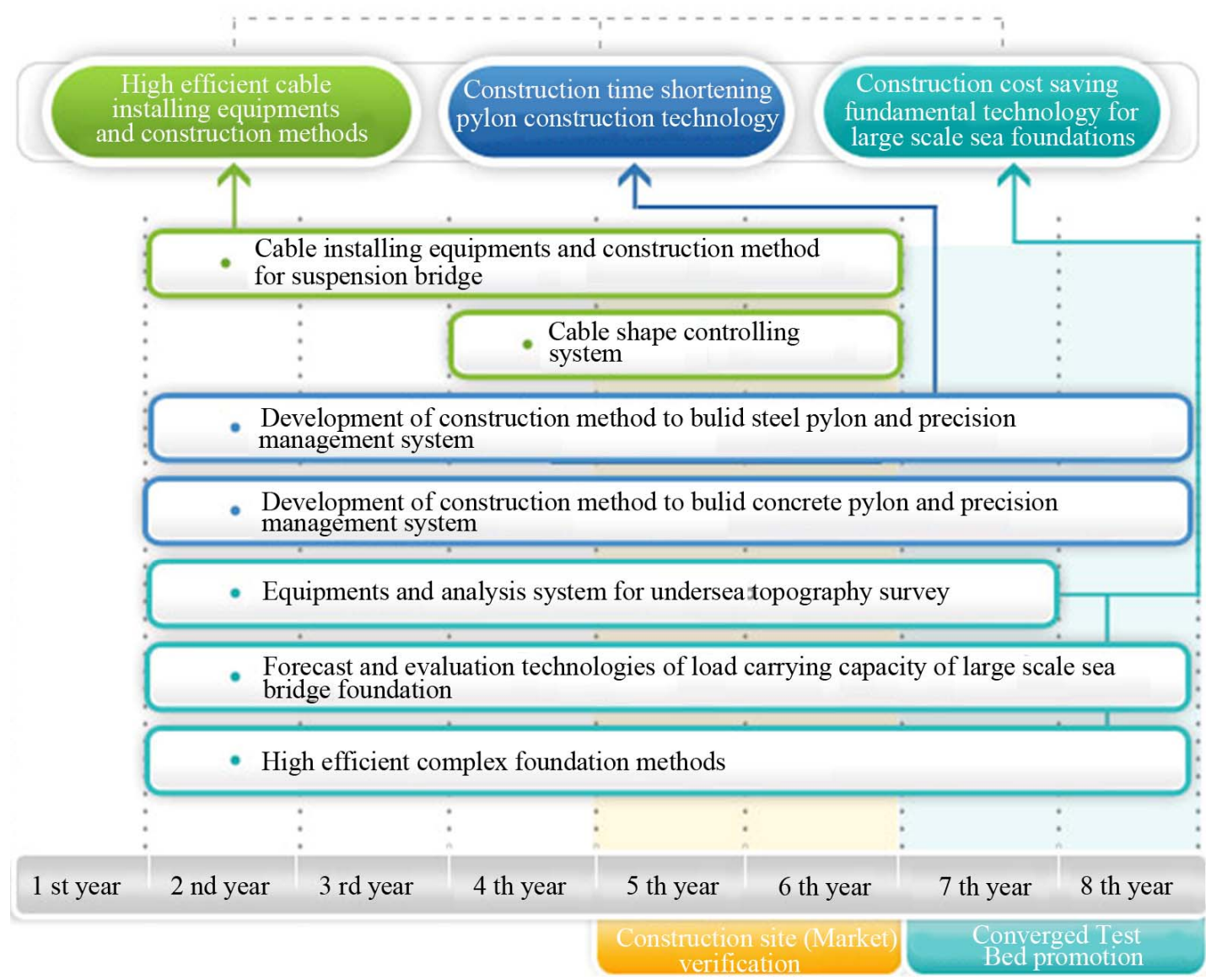

Figure 3. TRM of core project 3.

main cables during construction.

(1) Development of AS erection equipment and method

The AS method processes as follows: a steel wire with diameter of about $5 \mathrm{~mm}$ coiled around a reel is looped on to the spinning wheel on site; the strand is formed by repeatedly traveling the spinning wheel between the anchorages located at both ends of the bridge; once the desired amount of strands has been spun, the strands are packed together to complete the main cable (Figure 4). The spun wire is tensioned with a tension force smaller than that in free-hang state. Throughout the motion of the spinning wheel, the wire is automatically loaded in the cable formers disposed at regular intervals along the catwalk. After the formation of the strand according to the repeated traveling of the wheel, the tasks for the erec- tion of the main cable are conducted automatically by measuring and controlling the shape by strand unit [2].

The AS erection equipment includes the catwalk system corresponding to an aerial workshop, the reel fabrication equipment for the continuous operation of the hauled wire, the hauling system for hauling the wire and introducing constant tension in the wire, the spinning system and cable shaping system $[3,4]$.

(2) Development of PPWS erection equipment and method

The PPWS erection method proceeds as follows: the strands prefabricated in factory by packing the wires disposed in parallel are transported after having been coiled around a reel and, the strands are hauled one by one on site (Figure 5). The PPWS erection equipment includes the catwalk system corresponding to an aerial workshop, 


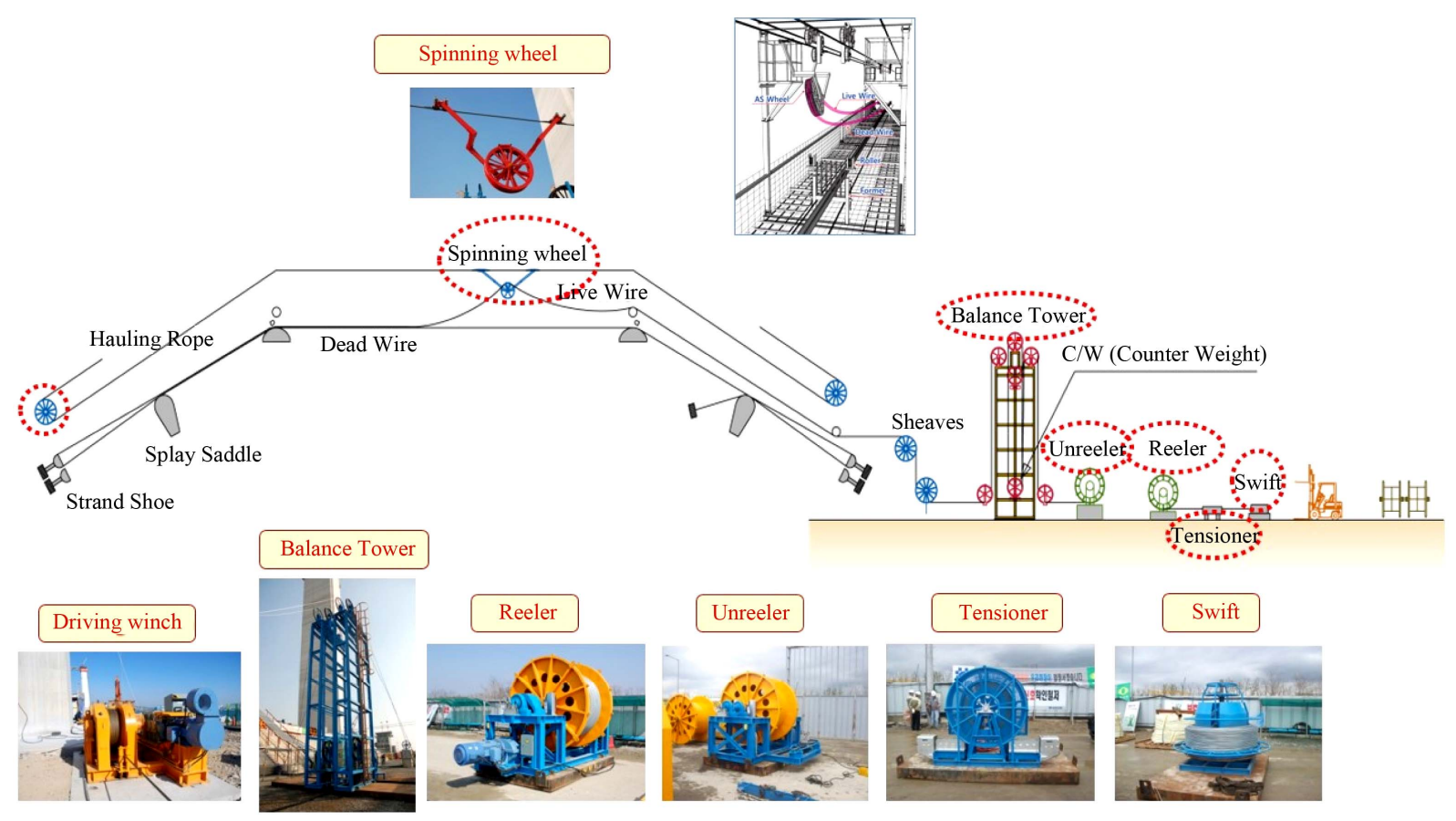

Figure 4. Erection equipment for AS cable.

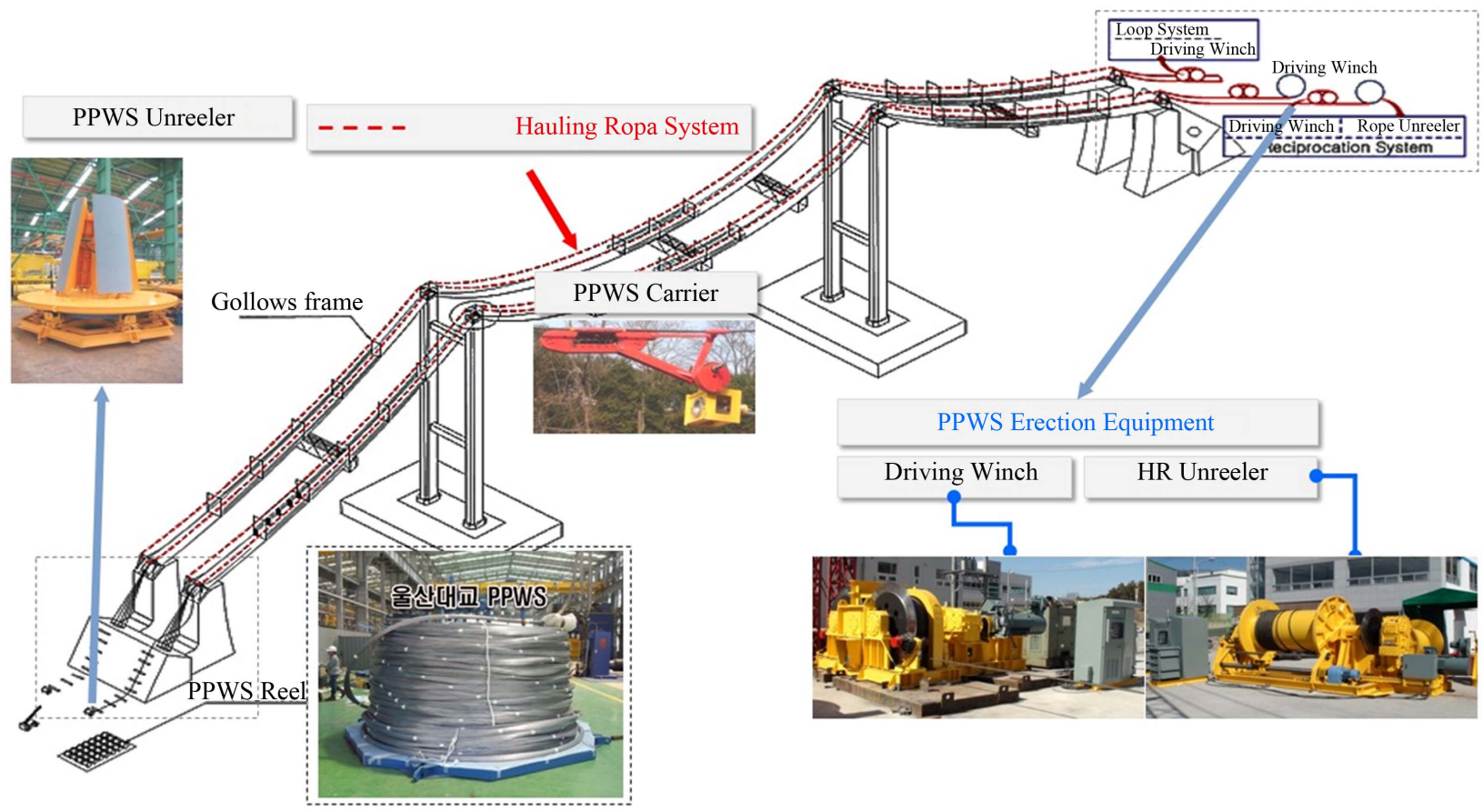

Figure 5. Erection equipment for PPWS cable.

hauling system for hauling the strands, unreeler, carrier and cable shaping system. Compared to the traditional AS method, the PPWS is less sensitive to the effect of wind during the erection, requires shortened construction period and simpler equipment. However, since the market producing PPWS cable is concentrated in China and Japan, supplying materials is difficult and, even if mate- rial can be supplied, the erection engineering and equipment are relying completely on foreign support. Accordingly, acquiring domestic and independent engineering technology for PPWS cable erection will minimize the drain of erection costs and equipment into foreign countries and promote our opportunity and position when participating to foreign suspension bridge projects. 
(3) Development of cable shape control system in suspension bridge

The cable shape control system in suspension bridge is necessary to achieve the target cable profile established during design at completion of the suspension bridge. The shape control of the cable is defined as the series of processes involving the precise measurement of the errors caused by the effects of temperature, wind speed and hauling system during erection, the construction errors introduced by the worker and, the shape control to realize the target shape for the erected cables. Since the span of suspension bridge reaches hundreds of meters to several kilometers, the latest measurement devices like conventional laser displacement sensor or sensors using GPS together with integrated system enabling to consider errors introduced by the refraction of light due to difference in the air density and curvature of the earth are required for the precise measurement of the shape [5].

\subsection{Development of Accelerated Erection Technology for Elevated Tower}

The major movable form systems for the erection of the concrete towers of super-long-span bridges are the ACS (Auto Climbing form System) and the slipform system, which differ by their operational methods. The slipform method, also called sliding method, erects the structure vertically or horizontally without construction joint and with a uniform shape. For elevated towers, this method proceeds by ascending vertically the yoke leg and form panel using a vertical jack supported embedded inside the concrete body of the tower. During the ascension, concrete is placed continuously. A total of 5 processes (assembling of form, assembling of rebar, concrete placing, curing, removal of form) are conducted repeatedly and simultaneously, which make this method significantly shorter than other methods even in view of the period needed for installation and dismantlement (Figure 6). The core technologies of the slipform method are the design and fabrication of a slipform system adaptable to tapered section, the automatic ascension of the slipform, the precise measurement of the position, the shape con-

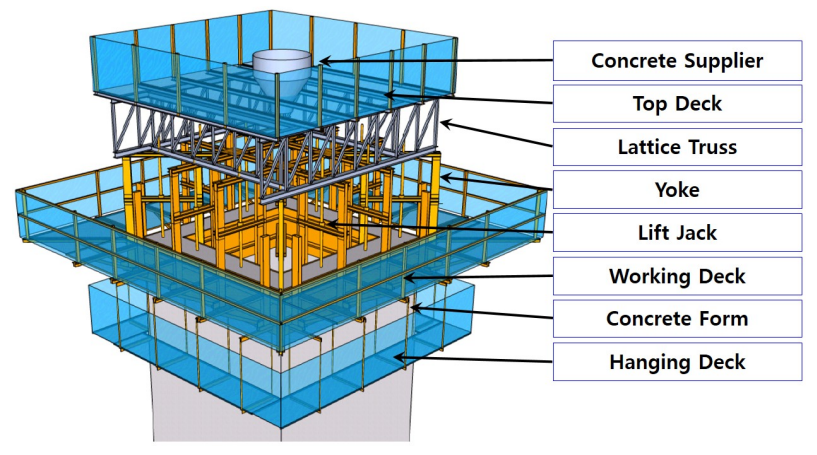

Figure 6. Tower erection using slipform. trol of the tower and, the design and fabrication of lightweight form system.

(1) Development of design and fabrication technologies for tapered slipform

The towers of long-span bridges generally present tapered section in which the section changes gradually from the top of the foundation to the top of the tower. When the section of the tower varies with respect to the height, the slipform system should be designed to be adaptable. The tapered slipform system is composed by a concrete silo for the placing of concrete, a top-deck, a lattice truss, the yoke, the ascending device, the workingdeck, the hanging-deck and the form panel. Research to optimize and improve the structure of each of these components has been conducted [6,7].

(2) Design of slipform control system

In order to ascend the slipform system without eccentricity, the capacity of the hydraulic pump must be determined to transmit simultaneously the hydraulic pressure to several jacks. In addition, the hydraulic manifold and hydraulic hose should also be constituted and operated suitably. However, the current method in which the hydraulic jack is operated by visual verification presents limitation for precise control. Accordingly, an automated hydraulic system enabling to ascend or descend precisely the jack should be developed. Moreover, when the elevated tower is erected using slipform system, errors in the verticality occur because of deformation of the form due to eccentric loading of the hoop reinforcement waiting for assembling at the top of the slipform or deformation of the form due to partial ascension of the form. Therefore, an integrated shape control system for elevated towers must be developed. This system should include positioning and shape control for the construction quality improvement of slipform system, sensors for the efficiency of error calibration, analysis and processing of the measurement of each sensor, and control of tapered slipform for the minimization of errors in the verticality and position (Figure 7).

(3) Design and fabrication technology of lightweight form system

The conventional slipform systems mostly composed by steel and wood present difficulties in their assembling, installation and quality control regard to the construction characteristics of super-long-span bridges in offshore areas. In the case of the application of lightweight form system with significantly reduced weight and offering easy moldability, the device itself can be maintained in satisfactory state and the management of the erection equipment can be more effective. Accordingly, research is dedicated to the minimization of the weight of the slipform by using lightweight material and the modularization of the components so as to adapt efficiently with irregular section and shorten effectively the time needed 

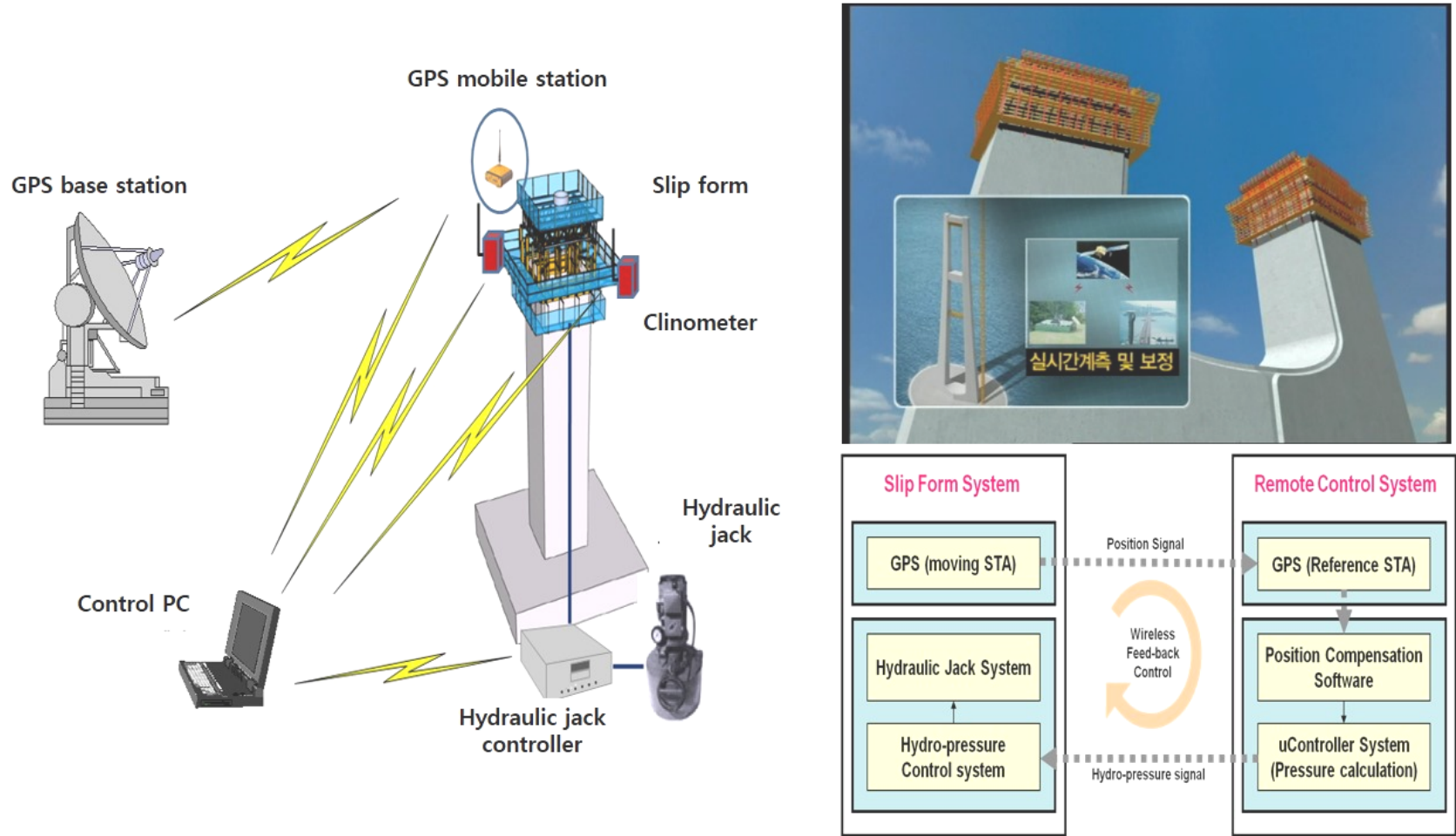

Figure 7. Smart control of slip-form system.

for the fabrication and assembling of the form (Figure 8).

\subsection{Development of Cost-Saving Large Scale Foundations}

The towers of super-long-span bridges are mostly located offshore. In order to guarantee the stability of such structures, priority should be given to securing technologies for the survey, design and construction under deep water and soft soil conditions. Large scale offshore foundations are generally designed using conservative soil parameters due to the difficulty in surveying the offshore soil. Accordingly, improving the reliability and economic efficiency of offshore foundations by computing the design soil parameters based on precise soil survey results is required. In addition, the precise forecast of the bearing capacity and settlement of offshore foundations is primordial for the improvement of the economic efficiency. Since the evaluation of the bearing capacity by in-situ loading test is extremely costly, need is to develop an economically efficient test method enabling the evaluation of the bearing capacity. Moreover, the recent occurrence of large scale earthquakes in China and Japan together with the increase of seismic events in the marine areas around Korea also emphasizes the necessity to develop strong seismic offshore foundations. A large portion of the long-span bridges planned in the western and southern coasts of Korea will be erected in areas featured by soft soil, deep water and rapid current drift. This implies that tremendous costs will be required for the construction of the offshore foundations. Therefore, research is led to develop cost-saving hybrid foundations enabling to overcome unfavorable soil conditions of the towers.

(1) Development of submarine soil survey equipment and analysis system

Most of the submarine soil surveys performed to date for the design and erection of the foundation structure of sea-crossing bridges in Korea applied common inshore boring equipment and in-situ equipment using low waterdepth barge at depth around $20 \mathrm{~m}$. However, the tower foundations of super-long-span bridges are likely to be erected at depth deeper than $20 \mathrm{~m}$, which means that the conventional barge will lose efficiency. Accordingly, economically efficient and effective submarine soil survey equipment should be developed to achieve efficient design and construction of large scale offshore foundations. The developed system is a floating type unmanned automated boring equipment enabling to derive more than 3 design parameters per depth down to a depth of 50 $\mathrm{m}$ or water-depth of $100 \mathrm{~m}$ (Figure 9).

(2) Development of forecast and evaluation techniques of the bearing capacity of large offshore foundations

Predicting exactly the bearing capacity and settlement is primordial to secure economic efficiency of large scale offshore foundations. Since the soil characteristics in Korea and overseas are extremely different, the computa- 


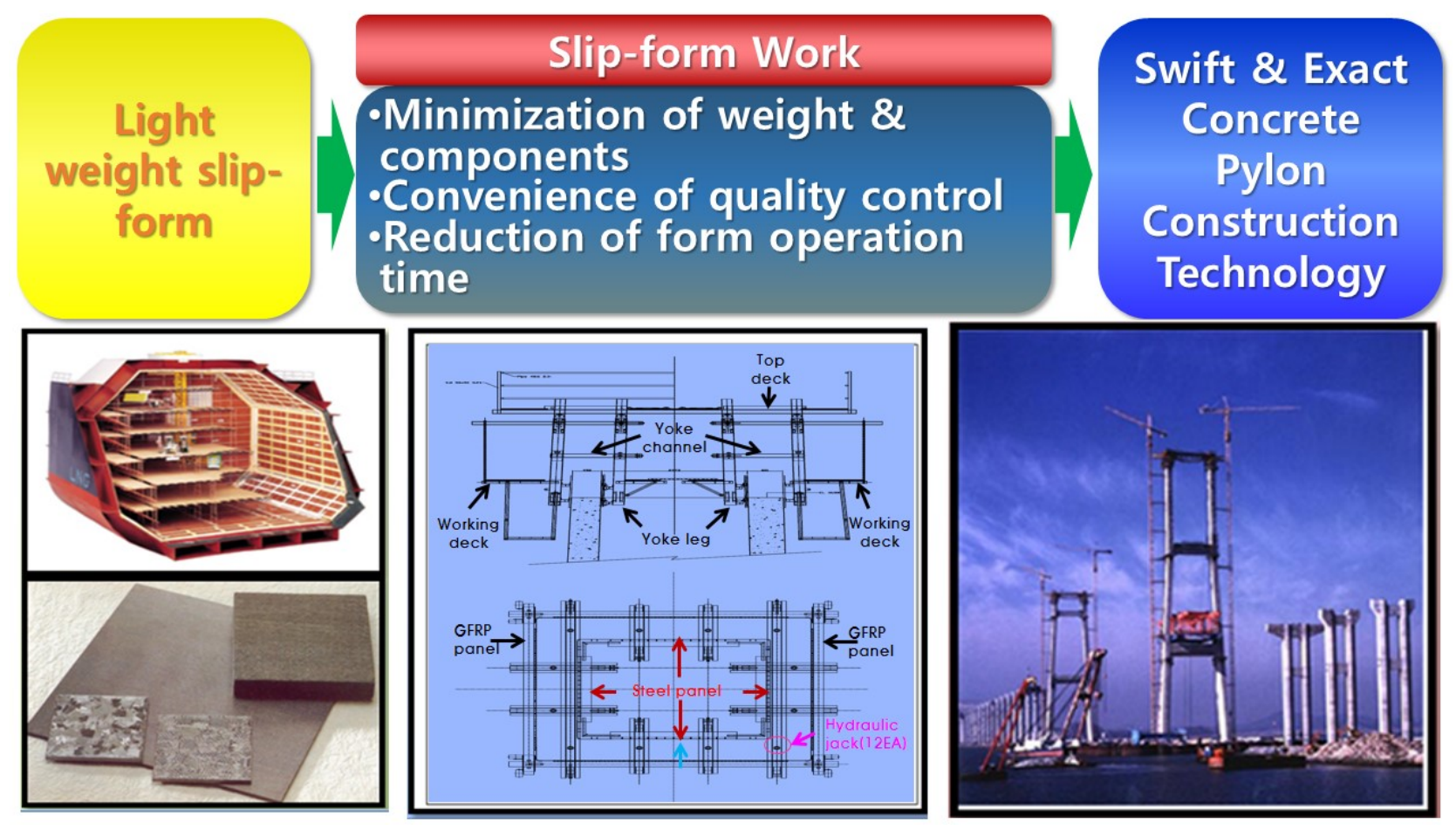

Figure 8. Optimizing \& minimizing the slip-form system.
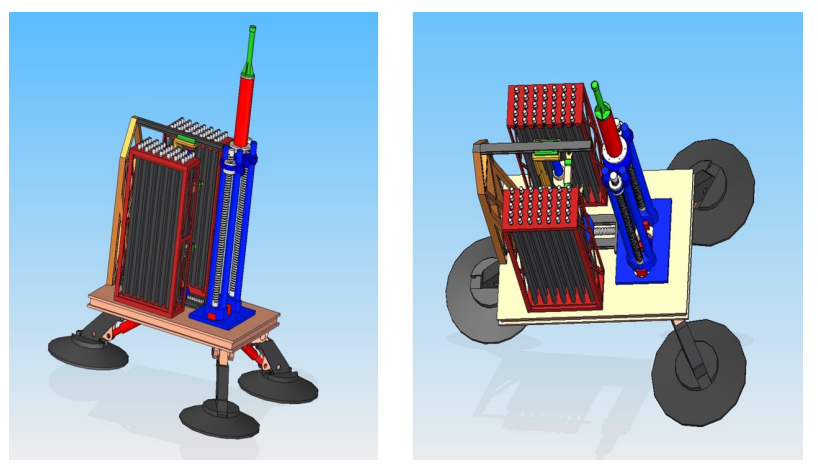

Figure 9. Conceptual drawing of floating detection equipment for submarine soil survey.

tion of the bearing capacity fitted to the domestic characteristics is necessary together with the development of LRFD design technology. Besides, need is for research on the settlement analysis considering the pile-foundation plate-pile interaction of the tower foundation in which piles are disposed in group. Moreover, need is also to develop bi-directional high-pressure loading test device to secure the exactness and economic efficiency of the loading test performed to verify the load bearing capacity of the large scale foundations constructed offshore.

(3) Development of highly efficient hybrid foundation technology

The continuous lengthening of the span of cable-supported bridges results in the increase of the scale of off- shore foundations. In addition, the increase of straitcrossing large scale marine bridge projects requires the installation of tower foundations in deep depths. Such situation implies the need for diverse methods enabling to construct economically the foundations of large scale bridges. Accordingly, seismic isolation system resisting to ground acceleration of $0.5 \mathrm{~g}$, foundations using walled steel pipe piles applicable to soft soils at depth of $100 \mathrm{~m}$ and highly efficient hybrid foundation applicable to water depth exceeding $50 \mathrm{~m}$ are developed to prepare for deep depths, soft soils and earthquakes.

\section{Conclusions}

This paper presented the development of construction technologies for long-span cable-supported bridges enabling accelerated construction and coast saving in order to secure our international competitiveness. The following effects are expected through the achievement of these objectives.

1) There is only 2 to 3 highly efficient cable erection equipment worldwide, which implies a complete dependence on foreign technology in this field. Achieving our objectives will provide substitute to foreign import and allow us to secure a leading or competitive position when participating in foreign projects through self-relying technology.

2) In the field of tower erection, the localization of automated slipform system will solve the delicate technical problem of erecting towers higher than $400 \mathrm{~m}$ and 
promote economically efficient erection of concrete tower. Significant reduction of the construction cost will also be realized through accelerated and effective construction owing to rapid decision-making of the calibration of construction errors, eased quality control of the structure and precise construction management technology.

3) In the field of foundation erection, the results of R\&D will secure technological level superior or equivalent to that of advanced countries, achieve efficient design of foundation structures as well as cost-saving construction technology and will be applicable to the erection of the foundations of large scale sea-crossing bridges and special structures.

\section{Acknowledgements}

This work was supported by the "Development of accelerated construction technologies for high pylons” project of the Super Long Span Bridge R\&D Program. The authors express their gratitude for the support.

\section{REFERENCES}

[1] Korea Institute of Construction \& Transportation Technology Evaluation and Planning, "Detailed Planning Study for Super-Long-Span Bridge R\&BD Project,” 2008.

[2] H. S. Choi and J. H. Kim, "Construction Method of Main Cable for Suspension Bridges," Magazine and Journal of Korean Society of Steel Construction, Vol. 20, No. 2, 2008, pp. 79-86.

[3] M. J. Ryall, G. A. R. Parke and J. E. Harding, “The Manual of Bridge Engineering,” Thomas Telford Ltd., 2000.

[4] Y. Yasutsugu and F. Rouvillain, "Cable Construction of the Great Belt East Bridge,” Foundation of Bridge, Vol. 97, No. 5, 1997, pp. 15-22.

[5] J. H. Moon and S. P. Chang, "Shape Adjustment of the Main-Cable of Suspension Bridges,” Magazine and Journal of Korean Society of Steel Construction, Vol. 20, No. 2, 2008, pp. 47-53.

[6] Jinsung Construction Co. Ltd., "Erection and Quality Control Using Slip-Form System,” 2009.

[7] D. Thomas, "Slipform Works for Pylons-Machang Bridge,” GBG. 